\title{
Evolution of Marine Bars under Micro and Mesotidal Settings of Mahanadi Delta Coast
}

\author{
Kamal Nag ${ }^{1^{*}}$ \\ ${ }^{1}$ Department of Geography, Prabhat Kumar College, Contai, India. \\ Author's contribution \\ The sole author designed, analyzed, interpreted and prepared the manuscript. \\ Article Information \\ DOI: $10.9734 / A J G R / 2021 / v 4 i 391$ \\ Editor(s): \\ (1) Dr. Xu Chong, Institute of Geology, China. \\ Reviewers: \\ (1) M. Venkateshwarlu, CSIR-NGRI, India. \\ (2) Bouba, Apollinaire University of Maroua, Cameroon \\ Complete Peer review History: https://www.sdiarticle4.com/review-history/71674
}

Original Research Article

Received 18 May 2021

Accepted 21 July 2021

Published 26 July 2021

\begin{abstract}
Shoreward migration process of longshore bar is an important aspect of shoreline changes in the Mahanadi delta front. It involves coalescence of individual bars to form large complex bars just before welding on to the shoreline. Such welding sometimes results in the formation of large hook spits. Bar welding mechanism can be an extremely important form of natural beach nourishment. This study aims to detect stages of evolution of longshore bars and consequent welding with mainland. Multi-dated Landsat images have been used to detect evolution of longshore bar and welding processes. QGIS platform has been used to process images and compose required maps.
\end{abstract}

Keywords: Longshore bar; bar welding; shoreline; landsat; QGIS.

\section{INTRODUCTION}

Shore parallel marine bars are a major component of the coastal morphology and play a significant role in coastal sediment budget [1]. The geomorphic evolution of such marine bars varies considerably along wave and tide range gradients [2]. The relationship between shoreline morphological evolution and migration of a bar depends upon a number of factors. Swash bars tend to migrate landward under surf bores and swash processes at rates that can be quite high, but extremely variable, ranging from 64 to 86 $\mathrm{m} / \mathrm{yr}$. [3] to133-327myr [4], but an exceptional rate of $46 \mathrm{~m} / \mathrm{month}$, has also been reported [5]. Their migration and welding onto the adjacent beaches generally result in rapid, localized shoreline [6]. 
Shoreward migration process (in such wave dominated to mixed energy settings) of longshore bar under Mahanadi delta coast involves coalescence of individual bars to form large complex bars (300m to several $\mathrm{km}$ long) just before welding on to the shoreline $[7,8,9]$. Such welding sometimes results in the formation of large hook spits [10,4,11]. Bar welding mechanism can, thus, be an extremely important form of natural beach nourishment, attaining, in some cases, several millions of $\mathrm{m} 3$ in the course of a single welding event $[12,13]$. Where the ebb delta is devoid of swash bars, Shoreline erosion can be observed on the down-drift side of the inlet $[10,14]$. The pattern of shoreline erosion and deposition in the vicinity of such inlets is controlled by cycles of ebb-tidal delta growth (swash bar formation) and decay (bar welding) that last from 4 to 8 years on the east coast of the Mahanadi delta. This study aims to detect stages of evolution of longshore bars and consequent welding with mainland. Detection of such changes and quantification of rate of changes have are important for beach nourishment, prediction of coastal erosion, vulnerability indexing etc.

\section{STUDY AREA}

The present study has been conducted on southern part of Mahanadi delta front (Fig. 1).
Delta front of Mahanadi in micro and mesotidal settings commonly exhibits swash bars ranging in length from $300 \mathrm{~m}$ to several $\mathrm{km}$ that are built by the wave-induced accumulation of sand [7]. Evolution of longshore bar at the delta front, between Mahanadi and the mouth of Devi river (a distributary of Mahanadi) have been studied for a period of 43 years (from 1973 to 2016) (Fig. 2).

\section{DATA AND METHODS}

Landsat data has been collected from USGS (United States Geological Survey) Global Visualization Viewer (GloVis). Series of Landsat Satellite (Landsat 1-8) images have been made available to users since 2001 by USGS. According to USGS, all images are processed through the Level 1 Product Generation System (LPGS) with Cubic Convolution (CC) resampling and geo-registered with a tolerance level $<12 \mathrm{M}$ root mean square error. Multi-dated satellite images of 1973, 1990, 2001 and 2016 have been used in this study. Data processing works have been carried out in ERDAS IMAGINE and QGIS. Entire workflow consists of four segments- image processing, indices based image transformation, shoreline extraction and calculating geometric parameters.

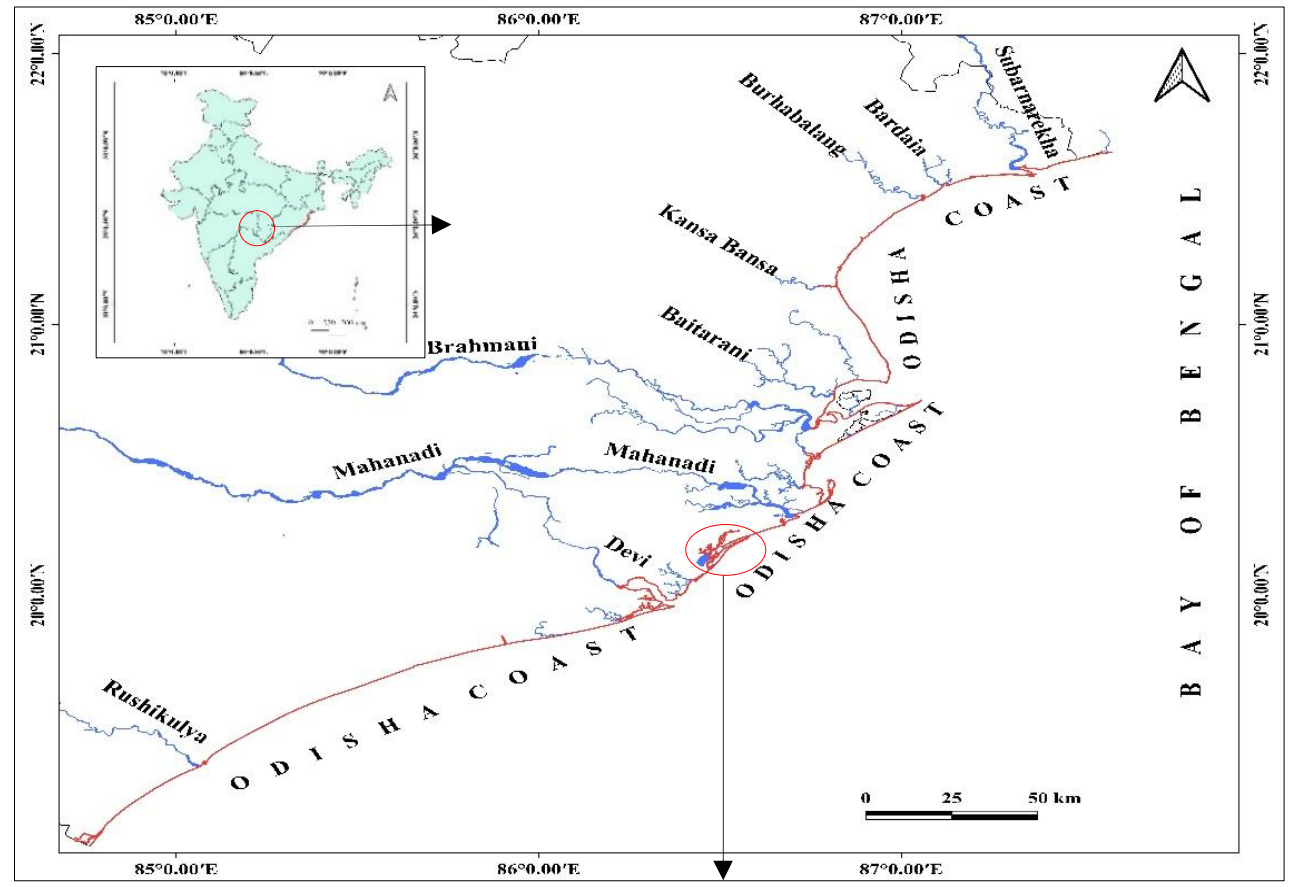

Fig. 1. Location of the study area 


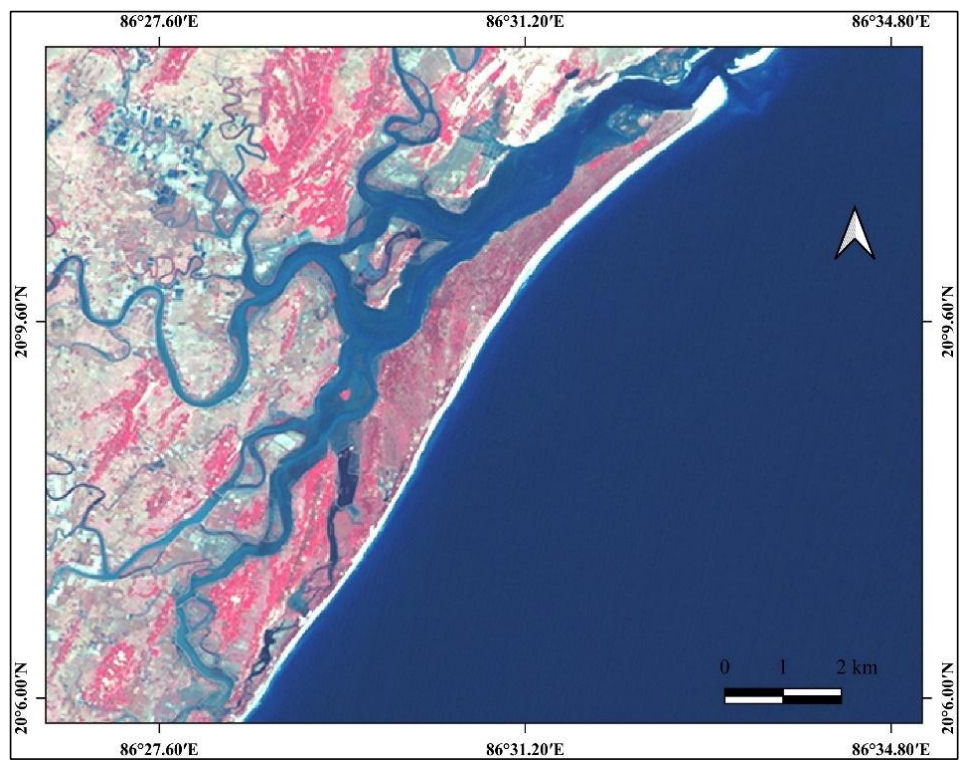

Fig. 2. Longshore Bar with tidal inlets (Landsat 5, ETM+, 2016)

\section{RESULTS AND DISCUSSION}

The conceptual model of the evolution of longshore bars as proposed by Kana et al. [9] comprises three stages. At the very first stage, an offshore bar developed off the shoreline and grows independently on the swash platform near the downdrift limits of the ebb-tidal delta. At the second stage, the bar starts to migrate landward and get attached to the beach face. Beach erosion may occur adjacent to both sides of the bar, and accretion continues directly in its lee side. During the final stage, it spreads along the shore in either direction from the point of attachment. A bulge in the shoreline may be observed where the bar attaches the mainland first (Fig. 3).

\subsection{Stages of the Evolution of Longshore Bar}

As per the conceptual model of shoreline changes (proposed by Kana and Mckee, [9]), interactivity between an ebb-tidal swash bar and the beach in a microtidal environment involves three stages of evolution. Longshore bar located south to the Paradeep coast, along the nearshore zone, revealed subsequent stages of their evolution.

\section{Stage-1: Detached offshore bar}

In 1973 map, longshore bar was located at a distant position from the mainland. A wide channel that is well connected to the open sea, separates the bar from the mainland. Sediment, carried out by the distributaries, easily finds an outlet to move into the open ocean. The evolution of the bar in subsequent stages also gives a glimpse of its former position. It can be assumed that in the past, prior to 1973, it was located at a further distance with a wider passage separating the bar from the mainland. In this stage longshore bar acts as a dissipater of waves from the east and north-east. It also promotes stability and accretion of the shoreline in its shelter.

\section{Stage-2: Proximity of longshore bar with the shoreline}

With passing time longshore bar increases in its length along the direction of longshore movement. Longshore movement is largely seasonal and completely reversal in winter. As a result of this phenomenon, it increases at both ends. An increment in length augments the sediment trapping process through the closure of passage to the open sea. Closure motion stimulates two major processes of bar attachment to the mainland, one is absolute stability of the shoreline behind the bar and the other is infilling of lagoon water. Open ocean front of the bar become less nourished and subjected to face wave and tide energy. Thus, open ocean front is attributed by negligible to moderate erosion. 


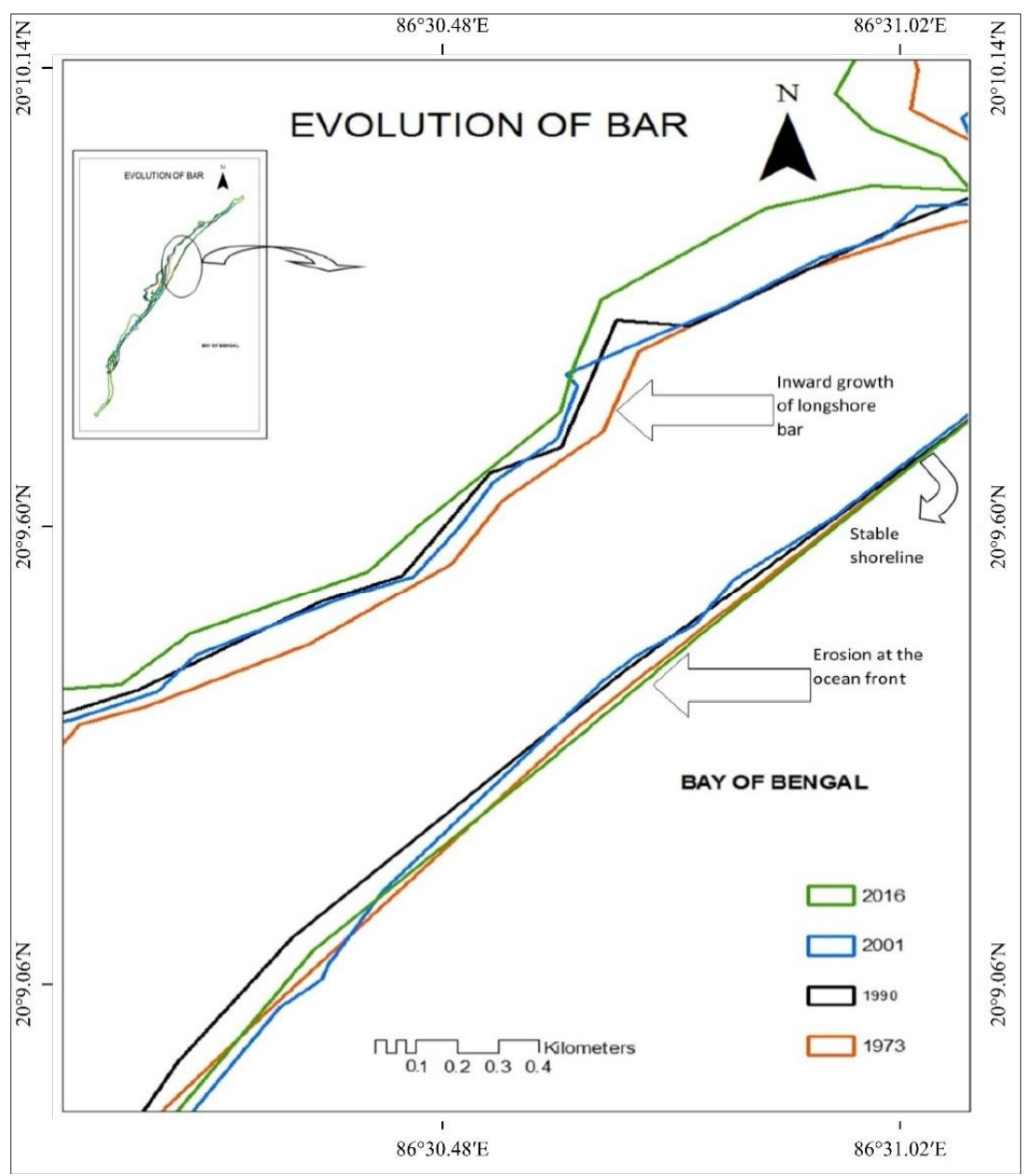

Fig. 3. Evolution of longshore bar

Stage-3: Bar integration and redistribution of the sediment in littoral cell system

In this stage longshore bar become fully integrated to the sheltered beaches, lagoon get filled up and the ocean front of the bar present high tide beaches. Almost entire distributaries behind the bar shifted out to find out new outlet to the open ocean.

\section{CONCLUSION}

Temporal analysis of the satellite data highlights the original nature of relationship of longshore bar to the shore in a microtidal to mesotidal environment. Merging and increase in length along the direction of longshore movement are the two major process of evolution of longshore bar. Longshore bar grew at a faster rate between 1990 and 2000. Rate of increase in areal expansion has been decreased since 2000 .
However, a comprehensive understanding on bar migration requires time series data on sediment influx to the shore, identification of changes in longshore drift, wave action and direction of wave energy concentration etc.

\section{ACKNOWLEDGEMENTS}

The author acknowledges USGS for making Landsat data freely available.

\section{COMPETING INTERESTS}

Author has declared that no competing interests exist.

\section{REFERENCES}

1. Oertel GF. Geomorphic cycles in ebb deltas and related patterns of shore 
erosion and accretion. J.Sediment. Petrol. 1977;47:1121-1131.

2. Davis RA Jr., Fitzgerald DM. Beaches and coasts. Blackwell, Victoria (Australia); 2004.

3. Smith JB, FitzGerald DM. Sediment transport at the Essex River inlet ebb-tidal delta, Massachusetts, USA. J. Coastal Res. 1994;10:752-774.

4. Gaudiano DJ, Kana TW. Shoal bypassing in mixed energy inlets: Geomorphic variables and empirical predictions for nine South Carolina inlets. J. Coastal Res. 2001;17:280-291.

5. Balouin Y, Howa H, Michel D. Swash platform morphology in the ebb-tidal delta of the Barra Novainlet, south Portugal. J. Coastal Res. 2001;17:784-791.

6. Hein CJ, Fallon AR, Rosen P, Hoagland $P$, Georgiou IY, FitzGerald DM, Fitzsimons G. Shoreline dynamics along a developed River Mouth Barrier Island: Multi-decadal cycles of erosion and event-driven mitigation. Frontiers in Earth Science. 2019;7.

DOI: $10.3389 /$ feart.2019.00103

7. Hine AC. Mechanisms of berm development and resulting beach growth along a barrier spit complex. Sedimentology. 1979;26:333-351.

DOI: 10.1111/j.1365-3091.1979.tb00913.x

8. Aubrey DG, Speer PE. Updrift migration of tidal inlets. J. Geol. 1984;92:531-546.

DOI: $10.1086 / 628890$
9. Kana TW, McKee PM. Relocation of captain sams inlet - 20 years later, paper presented at Coastal Sediment '03 Conference, Am. Soc. of Civ. Eng., St. Petersburg, Fla; 2003.

10. FitzGerald DM. Interactions between the ebb-tidal delta and landward shoreline: Price Inlet, South Carolina. J. Sediment. Petrol. 1984;54:1303-1318.

11. Robin N, Levoy F, Anthony EJ, Monfort O. Sand spit dynamics in a large tidal-range environment: insight from multiple LiDAR, UAV and hydrodynamic measurements on multiple spit hook development, breaching, reconstruction, and shoreline changes. Earth Surface Processes and Landforms; 2020.

DOI: 10.1002/esp.4924

12. Kana TW, Hayter EJ, Work PA. Mesoscale sediment transport at southeastern U.S. tidal inlets: Conceptual model applicable to mixed energy settings. J. Coastal Res. 1999;15:303-313.

13. Styles R, Brown M, Brutsché K, Li H, Beck $\mathrm{T}$, Sánchez A. Long-term morphological modeling of Barrier Island Tidal Inlets. Journal of Marine Science and Engineering. 2016;4(4):65.

DOI: $10.3390 / \mathrm{jmse} 4040065$

14. Nordstrom KF, Jackson NL, Farrell EJ, Rafferty P, Tengwall C. Restoring sediment to compensate for humaninduced erosion of an estuarine shore. Geomorphology. 2016;262:37-46. DOI: 10.1016/j.geomorph.2016.03.009

(c) 2021 Nag;; This is an Open Access article distributed under the terms of the Creative Commons Attribution License (http://creativecommons.org/licenses/by/4.0), which permits unrestricted use, distribution, and reproduction in any medium, provided the original work is properly cited.

Peer-review history:

The peer review history for this paper can be accessed here: https://www.sdiarticle4.com/review-history/71674 